\title{
PENGARUH KOMPETENSI DAN DISIPLIN KERJA TERHADAP KEPUASAN PELANGGAN DI KANTOR PELAYANAN KEKAYAAN NEGARA DAN LELANG (KPKNL) PALU
}

\author{
SRI DWI RATIH WIJAYANTI \\ LINA MAHARDIANA \\ RISNAWATI \\ Program Studi S1 Manajemen Fakultas Ekonomi Universitas Tadulako \\ Email: rateh04@gmail.com
}

\begin{abstract}
This study aims to: know and analyze whether the Competence and Discipline Work simultaneously and partially effect on Customer Satisfaction in the Office of State Assets and Auction (KPKNL) Palu. This study uses quantitative research which is a study that aims to explain the relationship between two or more variables with a sample of 49 customers and data analysis techniques used are multiple linear regression. The results of hypothesis analysis and testing can be concluded that: (1) based on regression test results obtained sig. F of $0.00<0.05$, which can be interpreted that the variable Competence and Work Discipline affect simultaneously to Customer Satisfaction. (2) based on regression test results obtained Competence variables have significance level $t$ sig. $0.010<\alpha 0.05$, which can be interpreted that the variable Competence partially significant effect on customer satisfaction. (3) based on the regression test results obtained variable Work Discipline has significance level $t$ sig. 0,000 $<\alpha$ 0.05, which can be interpreted that the variable Work Discipline partially significant effect on Customer Satisfaction.
\end{abstract}

Keywords: competence, work discipline, customer satisfaction

ABSTRAK

Penelitian ini bertujuan untuk: mengetahui dan menganalisis apakah Kompetensidan Disiplin Kerjaberpengaruh secara serempak dan parsial terhadap Kepuasan Pelanggan di Kantor Pelayanan Kekayaan Negara dan Lelang (KPKNL) Palu. Penelitian ini menggunakan penelitian kuantitatif yang merupakan penelitian yang bertujuan untuk menjelaskan hubungan antara dua variabel atau lebih dengan sampel 49 pelanggan dan teknik analisis data yang digunakan adalah regresi linear berganda.Hasil analisis dan pengujian hipotesis dapat disimpulkan bahwa: (1) berdasarkan hasil uji regresi diperoleh sig. F sebesar $0,00<0,05$, yang dapat diartikan bahwa variabel Kompetensidan Disiplin Kerjaberpengaruh secara serempak terhadap Kepuasan Pelanggan. (2) berdasarkan hasil uji regresi diperoleh variabel Kompetensimemiliki tingkat signifikasi t sig. $0,010<\alpha 0,05$, yang dapat diartikan bahwa variabel Kompetensisecara parsial berpengaruh signifikan terhadap kepuasan pelanggan. (3) berdasarkan hasil uji regresi diperoleh variabel Disiplin Kerja memiliki tingkat signifikasi t sig. $0,000<\alpha 0,05$, yang dapat diartikan bahwa variabel Disiplin Kerja secara parsial berpengaruh signifikan terhadap Kepuasan Pelanggan.

Kata kunci: kompetensi, disiplin kerja, kepuasan pelanggan

\section{PENDAHULUAN}

\section{Latar Belakang}

Kantor atau instansi tentunya tidak lepas dari kegiatan pelayanan, dalam hal ini peran SDM sangat menentukan, karena SDM merupakan satu-satunya sumber daya yang memiliki akal perasaan, keinginan, pengetahuan, keterampilan, dorongan, daya dan karya (rasio, rasa dan karsa). Menurut Sutrisno (2009:4) sumber daya manusia adalah pegawai yang siap, mampu, dan siaga dalam mencapai tujuan-tujuan organisasi.

Wibowo (2007:280) sumber daya manusia yang baik serta mempunyai kompetensi dan disiplin kerja yang tinggi akan dapat menunjang kemampuan organisasi untuk memberikan pelayanan kepada pelanggan dan mencapai tujuan yang telah ditetapkan. Setiap organisasi dibentuk untuk mencapai 
Wijayanti, S.D.R.

tujuan tertentu, dan apabila tujuan tersebut tercapai, organisasi dapat dikatakan berhasil. Keadaan tersebut membuat kompetensi sumber daya manusia semakin penting, baik bagi eksekutif, manajer maupun pekerja.

Sutrisno(2009:203) kompetensi sebagai karakteristik yang mendasari seseorang dan berkaitan dengan efektivitas kinerja individu dalam pekerjaannya. Berdasarkan definisi tersebut mengandung makna kompetensi adalah bagian kepribadian yang mendalam dan melekat kepada seseorang serta prilaku yang dapat diprediksi pada berbagai keadaan dan tugas pekerjaaan. Pegawai yang mempunyai kompetensi kerja yang baik tentu akan mudah untuk melaksanakan semua tanggung jawab pekerjaan, mampu membaca situasi dan permasalahan yang terjadi dalam pekerjaan serta dapat memberikan respon yang tepat dan memiliki penyesuaian diri yang baik dengan lingkunganya.

Disamping kompetensi, dalam sebuah instansi sangat perlu diterapkannya disiplin kerja pada setiap pegawai, karena dengan adanya penerapan disiplin kerja pegawai dapat lebih bertanggung jawab terhadap tugasnya sehingga kinerjanya akan lebih baik dan mampu memberikan kepuasan terhadap pelanggan dengan pelayanan yang baik. Disiplin kerja pada pegawai sangat dibutuhkan, karena tujuan perusahaan akan sukar dicapai bila tidak ada disiplin kerja. Sutrisno (2009:86) mendefinisikan disiplin adalah sikap kesediaan dan kerelaan seseorang untuk mematuhi dan menaati norma-norma peraturan yang berlaku disekitarnya.

Keberadaan pelanggan adalah faktor penting dalam mencapai tujuan, maka perusahaan semakin menyadari betapa pentingnya permintaan pelanggan. Perusahaan harus mampu memberikan kepuasan kepada para pelanggannya. Oleh karena itu, dalam melayani pasar pelanggan maka perusahaan harus mengerti kebutuhan (need) dan keinginan (wants) pelanggan, sehingga pelanggan mendapatkan kepuasan yang optimal. Semakin baik kompetensi dan kedisiplinan karyawan didalam perusahaan tersebut, semakin tinggi pula kepuasan yang akan diterima oleh pelanggan.

Observasi dilakukan di Kantor Pelayanan Kekayaan Negara dan Lelang (KPKNL) Palu. KPKNL merupakan unit organisasi yang diberi mandat oleh Kantor Pusat DJKN (Direktorat Jenderal kekayaan Negara) untuk mengelola kekayaan negara secara maksimal untuk membenahi manajemen aset negara menuju terlaksananya tertib administrasi, tertib hukum dan tertib fisik. Sehingga terwujud pengelolaan kekayaan negara yang optimal satuan kerjasatuan kerja (satker) yang berada diwilayah tersebut.Berdasarkan mandat yang diberikan DJKN (Direktorat Jenderal kekayaan Negara) kepada KPKNL PALU yang merupakan satusatunya perusahaan yang bergerak dibidang pengelolaan kekayaan Negara yang ada di Sulawesi Tengah ini, maka kompetensi dan disiplin kerja para pegawainya sangat dibutuhkan dalam hal melayani pelanggan.

\section{KAJIAN LITERATUR DAN PENGEMBANGAN HIPOTESIS}

\section{Pengertian Kompetensi}

Secara harafiah, kompetensi berasal dari kata competence yang artinya kecakapan, kemampuan dan wewenang. Adapun secara etimologi, kompetensi diartikan sebagai dimensi perilaku keahlian atau keunggulan pemimpin atau staf mempunyai keterampilan, pengetahuan dan perilaku yang baik, Sutrisno (2009:202).

Menurut Sutrisno (2009:202),mengatakan kompetensi adalah suatu yang mendasari karakteristik dari suatu individu yang dihubungkan dengan hasil yang diperoleh dalam suatu pekerjaan. Berdasarkan definisi tersebut mengandung makna kompetensi adalah bagian kepribadaian yang 
mendalam dan melekat kepada seseorang serta perilaku yang dapat diprediksi pada berbagai keadaan dan tugas pekerjaan.

\section{Dimensi Kompetensi}

Wibowo (2007:272) menyatakan bahwa kompetensi merupakan landasan dasar karakeristik orang dan mengindikasikan cara berperilaku dan berpikir, menyamakan situasi, dan mendukung untuk periode waktu cukup lama. Terdapat lima tipe karakteristik kompetensi, yaitu motif, sifat, konsep diri, pengetahuan dan keterampilan, berikut penjelasannya:

1. Motif adalah sesuatu yang secara konsisten dipikirkan atau diinginkan orang yang menyebabkan tindakan. Motif mendorng, mengarahkan, dan memilih perilaku menuju tindakan atau tujuan tertentu.

2. Sifat adalah karakteristik fisik dan respons yang konsisten terhadap situasi atau informasi. Kecepatan reaksi dan ketajaman mata merupakan ciri fisik kompetensi pilot tempur.

3. Konsep diri adalah sikap, nilai-nilai, atau citra diri seseorang. Percaya diri merupakan keyakinan orang bahwa mereka dapat efektif dalam hampir setiap situasi adalah bagian dari sikap diri orang.

4. Pengetahuan adalah informasi yang dimiliki orang dalam bidang spesifik. Pengetahuan adalah kompetensi yang kompleks. Skor pada teas pengetahuan sering gagal memprediksi prestasi kerja karena gagal mengukur pengetahuan dan keterampilan dengan cara yang sebenarnya dipergunakan dalam pekerjaan.

5. Keterampilan adalah kemampuan mengerjakan tugas fisik atau mental tertentu. Kompetensi mental atau keterampilan kognitif termasuk berpikir analitis dan konseptual.

\section{Pengertian Disiplin Kerja}

Disiplin menunjukkan suatu kondisi atau sikap hormat yang ada pada diri karyawan terhadap peraturan dan ketetapan perusahaan, dengan demikian bila peraturan atau ketetapan yang ada dalam perusahaan itu diabaikan, atau sering dilanggar, maka karyawan mempunyai disiplin kerja yang buruk. Sebaliknya, bila karywan tunduk pada ketetapan perusahaan, menggambarkan adanya kondisi disiplin yang baik, dalam arti yang lebih sempit dan lebih banyak dipakai, disiplin berarti tindakan yang diambil dengan penyeliaan untuk mengoreksi perilaku dan sikap yang salah pada sementara karyawan, Sutrisno (2009:86).

\section{Dimensi Disiplin Kerja}

1. Disiplin waktu berarti bersikap faktual terhadap waktu yang ditetapkan termasuk jam mulai kerja, jam istirahat, jam pulang kantor dan jam mulai serta penutupan rapat, seminar dan lain-lain.

2. Disiplin moral adalah disiplin yang keluar dari hati nurani untuk berusaha menepati atau menyelesaikan suatu pekerjaan.

3. Disiplin administratif adalah disiplin untuk megerjakan (dan atau tidak mengerjakan) seperti yang tertera dalam aturan atau kaidah yang ditetapkan sebelumnya. Kaidah tersebut dapat bersifat tertulis, tidak tertulis, dapat berupa suatu norma hukum, norma kesusilaan, peraturan kepegawaian dan lain-lain.

\section{Pengertian Kepuasan Pelanggan}

Perusahaan terus-menerus mencari dan menarik perhatian konsumen dengan menghadirkan produk barang maupun jasa yang sesuai dengan keinginan dan kebutuhannya dengan memberikan kinerja yang baik yang dihadirkan ke konsumen yang dapat memenuhi harapan konsumen, terpenuhi harapan konsumen dengan hasil kinerja yang ada dapat menghasilkan kepuasan. Kotler dan Keller dalam Adam (2010:98) menjelaskan kepuasan pelanggan adalah perasaan senang atau kekecewaan seseorang setelah membandingkan kinerja atau hasil yang dirasakan dibandingkan dengan harapannya. 
Wijayanti, S.D.R.

\section{Dimensi Kepuasan Pelanggan}

1. Tingkat Harapan yaitu mengukur besarnya harapan yang muncul atas pelayanan mekanik field yang diberikan kepada customer.

2. Tingkat Kinerja adalah mengukur besarnya pengalaman yang muncul atas pelayanan mekanik field yang diberikan kepada customer.

3. Kepuasan pelanggan merupakan perasaan seseoran pelanggan sebagai respon atau reaksi atas pelayanan atau kinerja yang diterimanya, dimana hal tersebut dapat diukur dengan membandingkan antara harapan customer atas pelayanan mekanik field.

4. Pelayanan adalah suatu kegiatan yang dilaksanakan dengan tujuan untuk memberi kepuasan kepada customer dalam melakukan perbaikan-perbaikan.

\section{Kerangka Pemikiran}

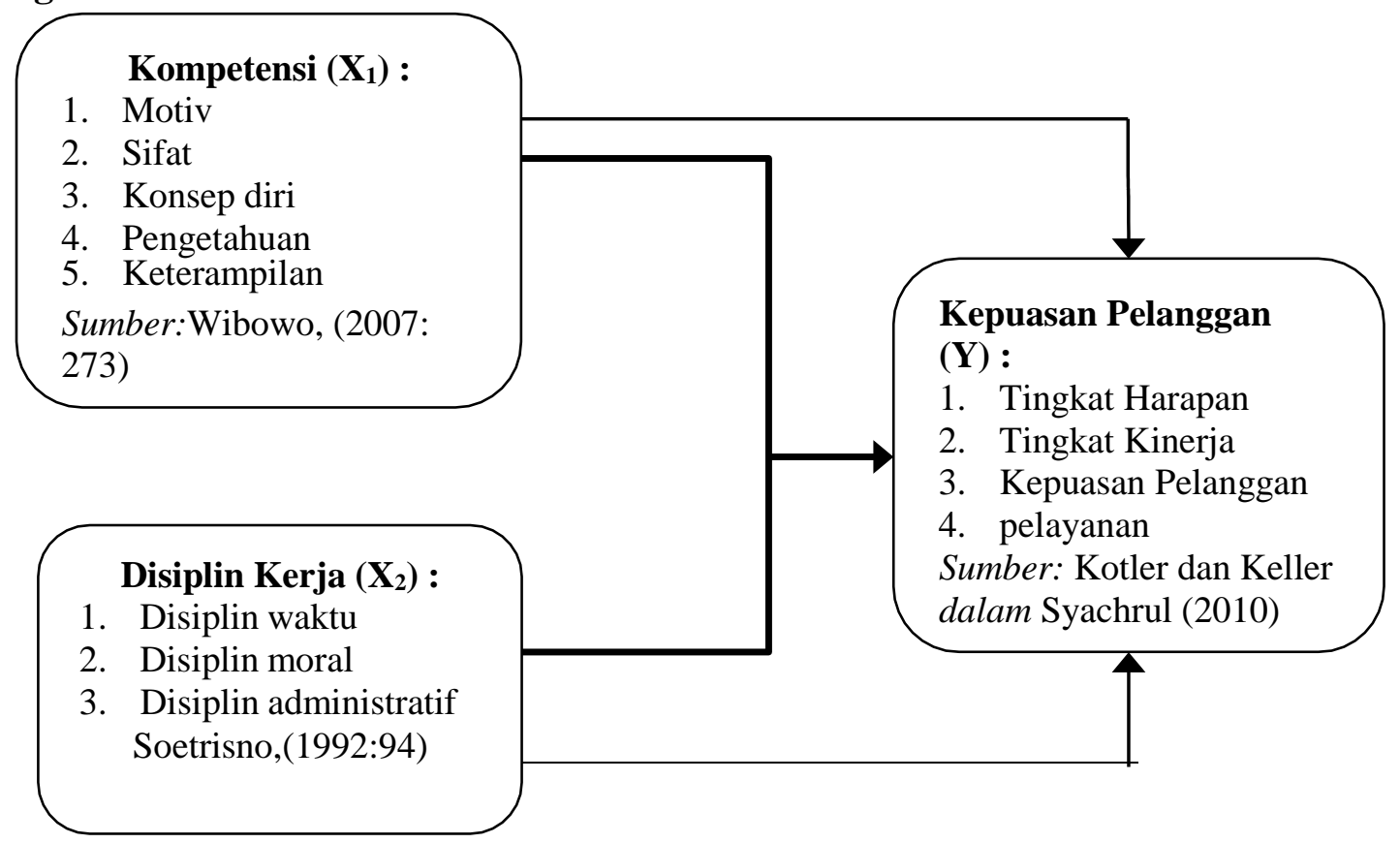

\section{Gambar 1 Kerangka Pemikiran}

\section{$\longrightarrow$ : Pengaruh secara parsial}

\section{Hipotesis}

1. Terdapat pengaruh Kompetensi dan Disiplin Kerja secara simultan terhadap Kepuasan Pelanggan pada Kantor Pelayanan Kekayaan Negara dan Lelang (KPKNL) Palu.

2. Terdapat pengaruh Kompetensi secara parsial terhadap Kepuasan Pelanggan pada Kantor Pelayanan Kekayaan Negara dan Lelang (PALU) Palu.

3. Terdapat pengaruh Disiplin Kerja secara parsial terhadap Kepuasan pelanggan pada Kantor Pelayanan Kekayaan Negara dan Lelang (KPKNL) Palu.

\section{METODE PENELITIAN}

\section{Jenis Penelitian}

Penelitian ini penulis menggunakan jenis penelitian asosiatif. Menurut Sugiyono (2014: 55), rumusan masalah asosiatif adalah suatu pertanyaan penelitian yang bersifat menanyakan hubungan antara dua variabel atau lebih. Menurut jenis datanya, penelitian ini merupakan penelitian kuantitatifkarena data yang disajikan dalam penelitian ini merupakan data dalam bentuk angka, yaitu 
seberapa besar pengaruh Kompetensi dan Disiplin Kerja yang dimiliki oleh pegawai KPKNL palu dan bagaimana pengaruhnya terhadap Kepuasan Pelanggan yang membeli barang lelang dikota Palu.

\section{Lokasi Penelitian}

Lokasi penelitian ini dipusatkan pada Kantor Pelayanan Kekayaan Negara dan Lelang (KPKNL) yang bertempat di Jl. Prof. Moh Yamin Kota Palu, Sulawesi Tengah. Alasan pemilihan lokasi ini disebabkan adanya fenomena terkait dengan variabel kompetensi dan disiplin kerja terhadap kepuasan pelanggan di Kantor Pelayanan Kekayaan Negara dan Lelang (KPKNL) Palu.

\section{Teknik Pengambilan Sampel}

Penelitian ini menggunakan sampling jenuh. Sampling jenuh adalah teknik penentuan sampel bila semua anggota populasi digunakan sebagai sampel. Istilah lain sampel jenuh adalah sensus, Sugiyono (2014:122-123). Sehingga sampel penelitian ini adalah seluruh pelanggan yang membeli barang lelang pada KPKNL Palu selama 10 bulan terakhir periode Juli 2016 - April 2017 yang tinggal di Kota Palu dan berjumlah 49 orang. Teknik penyebaran kuesioner terhadap pelanggan yaitu dengan cara menemui pelanggan langsung kerumahnya atau dengan cara bertemu dikantor KPKNL Palu.

Tabel 1.

Data Pelanggan Pembeli Barang Lelang KPKNL Palu selama Sepuluh(10) Bulan Terakhir

\begin{tabular}{|c|l|c|}
\hline No & \multicolumn{1}{|c|}{ Bulan } & Jumlah Pelanggan \\
\hline 1 & Juli & 3 \\
\hline 2 & Agustus & 3 \\
\hline 3 & September & 6 \\
\hline 4 & Oktober & 10 \\
\hline 5 & November & 9 \\
\hline 6 & Desember & 6 \\
\hline 7 & Januari & 2 \\
\hline 8 & Februari & 3 \\
\hline 9 & Maret Jumlah & 5 \\
\hline 10 & April & $\mathbf{4 9}$ \\
\hline \multicolumn{2}{|c|}{}
\end{tabular}

Sumber: Kantor Pelayanan Kekayaan Negara dan Lelang (KPKNL) Palu

\section{Teknik Pengumpulan Data}

1. Observasi merupakan suatu proses yang kompleks, suatu proses yang tersusun dari berbagai proses biologis dan psikologis, Sugiyono (2014:203).

2. Wawancara adalah sebuah dialog yang dilakukan oleh pewawancara untuk mendapatkan informasi dari terwawancara, Arikunto (2014:198).

3. Kuesioner merupakan teknik pengumpulan data yang dilakukan dengan cara memberi seperangkat pertanyaan atau pernyataan tertulis kepada responden untuk dijawabnya, Sugiyono (2014:199).

4. Dokumentasi dilakukan dengan mengumpulkan data-data dan penelusuran dokumen baik yang berupa tulisan maupun data-data tentang perusahaan yang telah dipublikasikan dan relevan dengan topik penelitian ini, berupa data sejarah singkat, srtuktur, visi, dan misi serta jumlah karyawan.

\section{Metode Analisis}

Menurut Sugiyono (2014:277) analisis regresi linear berganda digunakan untuk meramalkan bagaimana keadaan (naik turunnya) variabel dependen (kriterium), bila dua atau lebih variabel independen sebagai faktor prediktor dimanipulasi (dinaik turunkan nilainya). Persamaan regresi linear berganda dalam penelitian ini adalah: 
Wijayanti, S.D.R.

Dimana:

$$
\begin{array}{ll}
\mathrm{Y} & =\text { Kepuasan Pelanggan } \\
\mathrm{a} & =\text { Konstanta } \\
\mathrm{X}_{1} & =\text { Kompetensi } \\
\mathrm{X}_{2} & =\text { Disiplin Kerja } \\
\mathrm{b}_{1}-\mathrm{b}_{2} & =\text { Parameter Yang Diukur }
\end{array}
$$

\section{HASIL DAN PEMBAHASAN}

Tabel 2.

Hasil Perhitungan Regresi Linear Berganda

\begin{tabular}{lllll}
\hline \multicolumn{5}{c}{ Dependen Variabel $\mathbf{Y}=$ Kepuasan Pelanggan } \\
\hline Variabel & Koefisien Regresi & $\begin{array}{c}\text { Standar } \\
\text { Error }\end{array}$ & $\mathbf{T}$ & Sig \\
\hline Constanta & 2.166 & 0.389 & 5.570 & 0.000 \\
\hline $\mathrm{X}_{1}=$ Kompetensi & 0.277 & 0.103 & 2.679 & 0.010 \\
\hline $\mathrm{X}_{2}=$ Disiplin Kerja & 0.181 & 0.042 & 4.307 & 0.000 \\
\hline $\mathrm{R}$ & $=0,678^{\mathrm{a}}$ & & & \\
\hline $\mathrm{R}$-Square & $=0,460$ & & & \\
\hline F Statistik & $=19.561$ & & \\
\hline Sig. F & $=0,000<0,05$ & & \\
\hline
\end{tabular}

Sumber:Output For Windows Release 16.0

Berdasarkan nilai dari Tabel 2 di atas, maka persamaan regresi linear berganda dapat dirumuskan sebagai berikut:

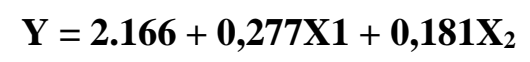

Persamaan di atas menunjukkan, variabel independen yang di analisis berupa variabel Kompetensi $\left(\mathrm{X}_{1}\right)$ dan Disiplin $\mathrm{Kerja}\left(\mathrm{X}_{2}\right)$ memberi pengaruh terhadap variabel independen Kepuasan Pelanggan (Y). Model analisis regresi kepuasan pelanggan di KPKNL Palu dapat dilihat sebagai berikut.

a. Untuk nilai konstanta sebesar 2.166 berarti Kepuasan Pelanggan di KPKNL Palu sebelum adanya variabel independen adalah sebesar 2.166.

b. Kompetensi $\left(\mathrm{X}_{1}\right)$ dengan nilai koefisien regresi 0,277 atau $27,7 \%$ ini berarti terjadi pengaruh positif antara kompetensi dan kepuasan pelanggan. Artinya jika kompetensi $\left(\mathrm{X}_{1}\right)$ meningkat maka akan meningkatkan kepuasan pelanggan (Y) di KPKNL Palu.

c. Disiplin Kerja $\left(\mathrm{X}_{2}\right)$ dengan nilai koefisien regresi 0,181 atau $18,1 \%$ ini berarti terjadi pengaruh positif antara disiplin kerja dan kepuasan pealanggan. Artinya jika disiplin kerja $\left(\mathrm{X}_{2}\right)$ meningkat maka akan meningkatkan kepuasan pelanggan (Y) di KPKNL Palu.

\section{Uji F (Simultan)}

Uji F bertujuan untuk mengetahui apakah variabel independen yakni kompetensi dan disiplin kerja yang diteliti memiliki pengaruh secara serempak terhadap variabel dependen yakni kepuasan pelanggan di Kantor Pelayanan Kekayaan Negara dan Lelang (KPKNL) Palu. Berdasarkan Tabel 2 terlihat hasil perhitungan diperoleh $F_{\text {hitung }}=19.561$ pada taraf nyata $\alpha=0,05$ dan nilai signifikansi $F=$ $0,000<0,05$. Kesimpulannya adalah variabel bebas secara bersama-sama (serempak) berpengaruh signifikan terhadap variabel terikat. Artinya bahwa variabel kompetensi dan disiplin kerja secara bersama-sama (serempak) berpengaruh signifikan terhadap variabel kepuasan pelanggan di Kantor Pelayanan Kekayaan Negara dan Lelang (KPKNL) Palu. Artinya hipotesis pertama yang menyatakan 
bahwa kompetensi dan disiplin kerja berpengaruh signifikan terhadap kepuasan pelanggan di Kantor Pelayanan Kekayaan Negara dan Lelang (KPKNL) Palu berdasarkan uji-F hasilnya terbukti.

\section{Uji t (Parsial)}

Uji t digunakan untuk mengetahui apakah variabel independen yakni kompetensi dan disiplin kerja yang diteliti memiliki pengaruh secara parsial terhadap variabel dependen yakni kepuasan pelanggan di Kantor Pelayanan Kekayaan negara dan Lelang (KPKNL) Palu. Adapun hasil uji hipotesis secara parsial dapat dilihat sebagai sebagai berikut:

a. Kompetensi $\left(\mathrm{X}_{1}\right)$

Hasil pengujian variabel kompetensi diperoleh tingkat signifikansi sebesar $0,010<0,05$. Artinya bahwa variabel kompetensi berpengaruh signifikan terhadap kepuasan pelanggan di KPKNL Palu. Berdasarkan hasil diatas, maka hipotesis kedua yang menyatakan bahwa kompetensi berpengaruh signifikan terhadap kepuasan pelanggan di KPKNL Palu berdasarkan uji-t hasilnya terbukti.

b. Disiplin Kerja $\left(\mathrm{X}_{2}\right)$

Hasil pengujian variabel disiplin kerja diperoleh tingkat signifikansi sebesar $0,000<0,05$. Artinya bahwa variabel disiplin kerja berpengaruh signifikan terhadap kepuasan pelanggan di KPKNL Palu. Berdasarkan hasil diatas, maka hipotesis ketiga yang menyatakan bahwa disiplin kerja berpengaruh signifikan terhadap kepuasan pelanggan di KPKNL Palu berdasarkan uji-t hasilnya terbukti.

\section{Pembahasan}

\section{Pengaruh Kompetensi dan Disiplin Kerja Terhadap Kepuasan Pelanggan di KPKNL Palu.}

Merujuk pada hasil pengujian hipotesis pertama yaitu Uji-F menunjukkan bahwa terdapat pengaruh secara serempak variabel kompetensi dan disiplin kerja yang signifikan terhadap kepuasan pelanggan di KPKNL Palu. Hal ini mengindikasikan bahwa kedua variabel independen tersebut memiliki pengaruh terhadap kepuasan pelanggan. Kompetensi merupakan hal yang tidak dapat dipisahkan dari pegawai karena menyangkut bagaimana pegawai tersebut menjalankan tugasnya sehingga tujuan organisasi dapat tercapai. Sedangkan disiplin yang baik mencerminkan besarnya rasa tanggung jawab seseorang terhadap tugas-tugas yang diberikan kepadanya.

Hal ini menunjukkan bahwa kompetensi pegawai di KPKNL Palu dari segi keterampilan menunjukkan bahwa pegawai di KPKNL Palu melaksanakan pekerjaan atau tugasnya dengan sebaikbaiknya sesuai dengan tugas yang diembannya, hal ini terlihat dari pegawai yang mampu melaksanakan program kerja sesuai dengan ketentuan KPKNL Palu. Sementara disiplin kerja juga merupakan hal penting bagi pegawai hal ini ditunjukkan dalam indikator disiplin administratif yaitu pegawai mematuhi aturan yang berlaku di KPKNL Palu seperti berpakaian rapi dan menjaga kesopanan dalam melayani pelanggan, apabila pegawai menerapkan kedisiplinan pada dirinya maka pelayanan yang diberikan kepada pelanggan akan maksimal.

Berdasarkan hasil distribusi frekuensi variabel kompetensi, semua indikator dinyatakan memiliki kontribusi terhadap variabel kepuasan pelanggan,dari 5 indikator kompetensi, indikator yang paling dominan dalam kepuasan pelanggan di KPKNL Palu adalah indikator keterampilan yang ditunjukkan dengan kemampuan pegawai dalam melaksanakan program kerja yang telah ditetapkan KPKNL Palu sehingga tujuan yang diharapkan dapat tercapai. Semakin tinggi nilai kompetensi akan semakin tinggi tingkat kepuasan yang dirasakan pelanggan.

Berdasarkan hasil distribusi variabel disiplin kerja semua indikator juga mempunyai kontribusi terhadap kepuasan pelanggan, namun yang paling dominan adalah indikator disiplin administratif yang ditunjukkan dengan perilaku pegawai yang mampu menaati peraturan di KPKNL Palu. Pegawai yang 
Wijayanti, S.D.R.

mempunyai disiplin administratif yang baik akan mempengaruhi perilakunya dalam suatu instansi. Semakin tinggi tingkat disiplin akan semakin tinggi kepuasan yang dirasakan pelanggan.

Penelitian secara parsial dilakukan oleh Cecile Delcourtet al, (2013)dengan hasil penelitiaan bahwa variabel kompetensi secara parsial berpengaruh signifikan terhadap kepuasan pelanggan dan loyalitas pelanggan. Penelitian mengenai hubungan disiplin kerja dengan kepuasan pelanggan juga diteliti oleh Agus Budi Purwanto dan Susanti Wahyunungsih studi dilakukan pada Hotel dikabupaten semarang (2013), dengan hasil penelitian bahwa terdapat pengaruh langsung secara positif antara kedisiplinan terhadap kepuasan pelanggan.

\section{Pengaruh Kompetensi Terhadap Kepuasan Pelanggan di KPKNL Palu}

Berdasarkan hasil pengujian hipotesis kedua yaitu Uji-t menunjukkan bahwa terdapat pengaruh kompetensi yang signifikan terhadap kepuasan pelanggan di KPKNL Palu. Hasil ini memberikan makna bahwa kompetensi memberikan kontribusi terhadap kepuasan pelanggan. Semakin tinggi nilai kompetensi yang dimiliki pegawai tersebut maka kepuasan pelanggan juga akan semakin meningkat. Hal ini sejalan dengan pernyataan Wibowo (2007:271) mengemukakan bahwa kompetensi adalah suatu kemampuan untuk melaksanakan atau melakukan suatu pekerjaan atau tugas yang dilandasi atas keterampilan dan pengetahuan serta didukung oleh sikap kerja yang dituntut oleh pekerjaan tersebut. Pegawai yang memiliki kompetensi tinggi akan memberi kontribusi yang tinggi terhadap pelayanan kepada pelanggan.

Indikator kompetensi yang dominan menurut tanggapan responden adalah dimensi keterampilan. Pegawai di KPKNL Palu mempunyai keterampilan yang baik hal ini ditunjukkan dengan pegawai mampu melaksanankan program kerja dengan benar dan mampu membantu rekan kerja apabila mendapatkan masalah dalam pekerjaannya. Keterampilan harus dimiliki pegawai untuk dapat melaksanakan pekerjaan sesuai dengan tugas yang diembannya. Pegawai diinstansi harus memahami dengan seksama kebutuhan dan keinginan pelanggan, dengan demikian perusahaan dapat memberikan pelayanan yang memuaskan bagi pelanggan.

Hasil penelitian ini relevan dengan penelitian yang dilakukan Yunia Insanatul Karimah studi dilakukan di PT Garuda Indonesia kantor cabang Surabaya (2016), dalam penelitian ini data dikumpulkan dengan kuesioner dan menggunakan menggunakan metode sensus dan pendekatan kuantitatif dengan analisis regresi linear berganda. Hasil penelitian menunjukkan bahwa variabel kompetensi berpengaruh secara signifikan terhadap kepuasan pelanggan.

\section{Pengaruh Disiplin KerjaTerhadap Kepuasan Pelanggan di KPKNL Palu}

Berdasarkan hasil pengujian hipotesis kedua yaitu Uji-t menunjukkan bahwa terdapat pengaruh disiplin kerja yang signifikan terhadap kepuasan pelanggan di KPKNL Palu. Hal ini bermakna bahwa disiplin kerja memberikan kontribusi terhadap kepuasan pelanggan. Disiplin kerja merupakan hal yang penting yang harus dimiliki pegawai dalam bekerja. Hal ini sejalan dengan pernyataan Sutrisno (2009:87) displin adalah sikap hormat terhadap peraturan dan ketetapan perusahaan, yang ada dalaam diri karyawan, yang menyebabkan ia dapat menyesuaikan diri dengan sukarela pada peraturan dan ketetapan perusahaan.

Indikator disiplin kerja yang dominan menurut tanggapan responden adalah indikator disiplin administratif yang ditunjukkan dengan para pegawai mematuhi aturan, selalu menjaga penampilan sesuai dengan ketentuan di KPKNL Palu dan menjaga kesopanan didalam maupun diluar kantor pada saat bertemu dengan pelanggan. Hal ini menunjukkan bahwa disiplin yang baik mencerminkan besarnya tanggung jawab pegawai terhadap tugas-tugas yang diberikan kepadanya dan pelayanan yang diberikan kepada pelanggan akan maksimal dan dapat memberi kepuasan kepada pelanggan. Diterapkannya disiplin bagi karyawan diharapkan akan mampu menciptakan nilai bagi perusahaan yang berasal dari pelanggan. Suatu bisnis dikatakan sukses jika berhasil mendapatkan, mempertahankan dan menumbuhkan rasa kepercayaan dari pelanggan, Adam (2010:93).Hal ini sejalan 
dengan penelitian Agus Budi Purwanto dan Susanti wahyuningsih ( studi pada hotel dikabupaten semarang, 2013) dengan hasil penelitian bahwa terdapat pengaruh langsung secara positif antara kedisplinan dan ketanggapan terhadap kepuasan pelanggan.

\section{KESIMPULAN DAN SARAN}

\section{Kesimpulan}

Berdasarkan hasil pembahasan penelitian yang telah dikemukakan diatas, maka penulis mengambil beberapa kesimpulan dari hasil penelitian ini sebagai berikut:

1. Kompetensi dan disiplin kerja secara serempak berpengaruh positif dan signifikan terhadap kepuasan pelanggan di Kantor Pelayanan Kekayaan Negara dan Lelang (KPKNL) Palu.

2. Kompetensi secara parsial berpengaruh positif dan signifikan terhadap kepuasan pelanggan di Kantor Pelayanan Kekayaan Negara dan Lelang (KPKNL) Palu.

3. Disiplin kerja secara parsial berpengaruh positif dan signifikan terhadap kepuasan pelanggan di Kantor Pelayanan Kekayaan Negara dan Lelang (KPKNL) Palu.

\section{Saran}

Berdasarkan pada penelitian yang telah dilakukan dan hasil kesimpulan yang diperoleh, maka saran yang diajukan peneliti dalam penelitian ini adalah sebagai berikut:

1. Untuk variabel kompetensi, perlu upaya untuk mempertahankan dan lebih memaksimalkan kompetensi pegawai pada KPKNL Palu melalui peningkatan pengetahuan dengan memberikan kesempatan seluas-luasnya untuk belajar sesuai dengan bidang pekerjaannya.

2. Untuk variabel disiplin kerja, hendaknya KPKNL Palu perlu mempertahankan disiplin kerja pegawai, sedangkan dari segi dimensi waktu ketegasan dalam disiplin pegawai harus ditegakkan. Penerapan hukuman bagi pegawai yang melanggar harus jelas dan sesuai dengan peraturan yang berlaku mulai dari teguran lisan, teguran tertulis dan sanksi yang berat.

3. Untuk variabel kepuasan pelanggan, diharapkan pegawai KPKNL Palu lebih meningkatkan pelayanan agar sesuai dengan harapan yang diinginkan pelanggan, dengan memberikan pelayanan dan kualitas jasa yang diharapakan pelanggan.

\section{REFERENSI}

Adam, Rosida. (2010). Manajemen Pemasaran, Lembaga Pengkajian Pembaharuan Hukum dan Kebijakan Publik (LP2HKP), Palu.

Arikunto, Suharsimi. (2014). Prosedur Penelitian: Suatu Pendekatan Praktik, Jakarta: PT. Rineka Cipta.

Cecile Delcourt, et al(2013). Effects Of Perceived Employe Emotional Competence On Customer Satisfaction And Loyalty The Mediating Role Of Rapport. Jurnal Manajemen Pelayanan Vol. 24, No. 1, 2013 hal 5-24 q Emerald Group.

Karimah, Yunia Insanatul. (2016). Pengaruh Kompetensi Kepemimpinan dan Budaya Organisasi Terhadap Kepuasan Pelanggan Melalui Perilaku Responsif (studi Pada PT Garuda Indonesia Kantor Cabang Surabaya). Business and Finance Journal, Volume 1, No. 1, March 2016.

Purwanto, Agus Budi dan Wahyuningsih, Susanti. (2013). Pengaruh Kedisiplinan dan Ketanggapan Terhadap Kepuasan Pelanggan Dengan Kualitas Pelayanan Sebagai Variabel intervening (Studi Pada Hotel Dikabupaten Semarang). Fokus Ekonomi Vol.8, No.2, Desember 2013: 103121.

Soetrisno, PH. (1992). Kapita Selekta Ekonomi. Edisi Kedua. Yogyakarta: Andi Offset.

Sugiyono. (2014). Metode Penelitian Bisnis,Bandung: Alfabeta.

Sutrisno. (2009). Manajemen Sumber Daya Manusia, Jakarta: Erlangga. 
Wijayanti, S.D.R.

Syachrul. (2010). Analisis Tingkat Kepuasan Pelanggan Terhadap Pelayanan Mekanik Field Pt

Trakindo Utama Samarinda.Jurnal Eksis, Vol.6, No.2, Agustus 2010: 1440 - 1605

Wibowo.(2007). Manajemen Kinerja, Jakarta: PT. Raja Grafindo Persada. 